\title{
Evaluation of the kinase domain of c-KIT in canine cutaneous mast cell tumors Joshua D Webster ${ }^{1,2}$, Matti Kiupel ${ }^{1,2}$ and Vilma Yuzbasiyan-Gurkan*1,3,4
}

\author{
Address: ${ }^{1}$ Comparative Medicine and Integrative Biology Program, College of Veterinary Medicine, Michigan State University, East Lansing, MI, \\ USA, ${ }^{2}$ Department of Pathobiolgy and Diagnostic Investigation, College of Veterinary Medicine, Michigan State University, East Lansing, MI, USA, \\ ${ }^{3}$ Department of Small Animal Clinical Sciences, College of Veterinary Medicine, Michigan State University, East Lansing, MI, USA and \\ ${ }^{4}$ Department of Microbiology and Molecular Genetics, College of Veterinary Medicine, Michigan State University, East Lansing, MI, USA \\ Email: Joshua D Webster - webste28@cvm.msu.edu; Matti Kiupel - kiupel@dcpah.msu.edu; Vilma Yuzbasiyan- \\ Gurkan* - yuzbasiyan@cvm.msu.edu \\ * Corresponding author
}

Published: 0I April 2006

BMC Cancer2006, 6:85 doi:10.1/86/147/-2407-6-85
Received: 14 December 2005

Accepted: 0 I April 2006

This article is available from: http://www.biomedcentral.com/I47/-2407/6/85

(c) 2006Webster et al; licensee BioMed Central Ltd.

This is an Open Access article distributed under the terms of the Creative Commons Attribution License (http://creativecommons.org/licenses/by/2.0), which permits unrestricted use, distribution, and reproduction in any medium, provided the original work is properly cited.

\begin{abstract}
Background: Mutations in the c-KIT proto-oncogene have been implicated in the progression of several neoplastic diseases, including gastrointestinal stromal tumors and mastocytosis in humans, and cutaneous mast cell tumors (MCTs) in canines. Mutations in human mastocytosis patients primarily occur in C-KIT exon 17, which encodes a portion of its kinase domain. In contrast, deletions and internal tandem duplication (ITD) mutations are found in the juxtamembrane domain of c-KIT in approximately I5\% of canine MCTs. In addition, ITD c-KIT mutations are significantly associated with aberrant KIT protein localization in canine MCTs. However, some canine MCTs have aberrant KIT localization but lack ITD c-KIT mutations, suggesting that other mutations or other factors may be responsible for aberrant KIT localization in these tumors.
\end{abstract}

Methods: In order to characterize the prevalence of mutations in the phospho-transferase portion of c-KIT's kinase domain in canine MCTs exons 16-20 of 33 canine MCTs from 33 dogs were amplified and sequenced. Additionally, in order to determine if mutations in c-KIT exon 17 are responsible for aberrant KIT localization in MCTs that lack juxtamembrane domain c-KIT mutations, c-KIT exon 17 was amplified and sequenced from 18 canine MCTs that showed an aberrant KIT localization pattern but did not have ITD c-KIT mutations.

Results: No mutations or polymorphisms were identified in exons 16-20 of any of the MCTs examined.

Conclusion: In conclusion, mutations in the phospho-transferase portion of c-KIT's kinase domain do not play an important role in the progression of canine cutaneous MCTs, or in the aberrant localization of KIT in canine MCTs.

\section{Background}

The $c$-KIT proto-oncogene encodes the type III receptor tyrosine kinase KIT, which consists of an extracellular ligand binding domain, a transmembrane domain, a nega- tive regulatory juxtamembrane domain and a split kinase domain [1-3] (Figure 1). In healthy humans as well as in dogs, $c$-KIT is expressed by multiple cell types including mast cells, germ cells, melanocytes, and hematopoietic 


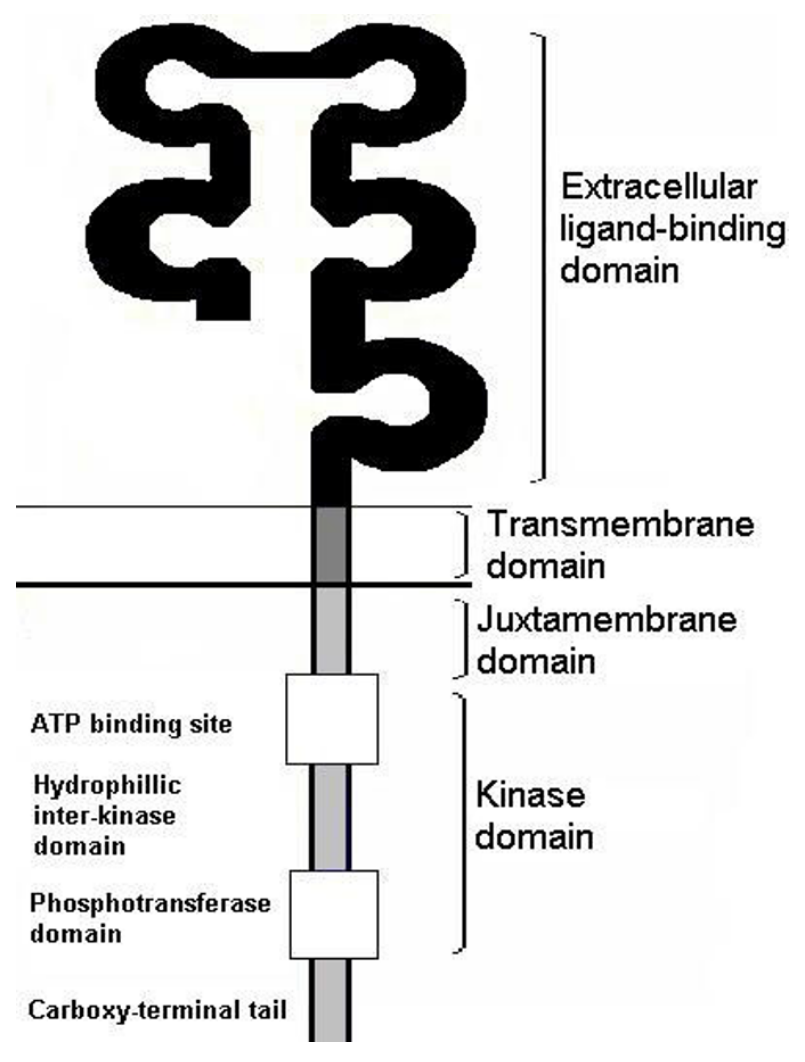

Figure I

Schematic diagram of the receptor tyrosine kinase KIT.

precursor cells [4-8]. Notably, in mast cells KIT and its ligand stem cell factor (SCF, also known as mast cell growth factor) [9-12] have been shown to be involved in cell survival, proliferation, differentiation, chemotaxis, degranulation, and fibronectin adhesion [10,13-17]. In human patients, mutations in the $c$-KIT proto-oncogene have been implicated in the pathogenesis of multiple neoplastic diseases, including mastocytosis, germ cell tumors, and gastrointestinal stromal tumors (GISTs) [18-23]. The locations of these $c$-KIT mutations vary between the different neoplastic diseases. The vast majority of mutations characterized in human patients with mastocytosis occur at codon 816 in exon 17, which encodes a portion of the kinase domain of KIT [19,24,25]. Mutations in germ cell tumors have been found in both the juxtamembrane domain and the kinase domain of c-KIT [21,22], while mutations in GISTs tend to occur in exon 11 of the juxtamembrane domain of $c$-KIT $[23,26,27]$. Despite their variation in location both, juxtamembrane domain and kinase domains $c$-KIT mutations result in a constitutively activated KIT protein that is phosphorylated in the absence of the ligand [18,21-23].
In recent years, $c$-KIT has been implicated in the pathogenesis of canine cutaneous mast cell tumors (MCTs), which are one of the most common neoplasms in dogs [28-32]. Internal tandem duplications (ITDs), deletions, and point mutations have been identified in the juxtamembrane domain of $c$-KIT in canine cutaneous MCTs [3335]. The reported incidence of $c$-KIT mutations has varied between different studies. In two studies that screened randomly selected cases submitted, mutations were identified in $15 \%$ of canine MCTs [35,36]. However, another study reported $c$-KIT mutations in $50 \%$ of canine MCTs that were seen in a referral oncology practice [37]. This discrepancy in the incidence of $c$-KIT mutations in canine MCTs is most likely due to the variations in case selection between these studies with the higher percentage reflecting ascertainment bias at the referral practice. Internal tandem duplication $c$-KIT mutations are the most common $[35,38]$, and therefore the most extensively studied $c$-KIT mutation in canine MCTs. All of the ITD mutations that have been studied thus far have been found to produce a constitutively activated product, thereby implicating $c$-KIT in the progression of canine MCTs [33,34,39]. Previous work by our laboratory has shown that $c$-KIT mutations are significantly associated with higher histologic grade MCTs [35], and that MCT patients with ITDs have a significantly worse prognosis as compared to patients without ITD mutations, thereby further implicating $c$-KIT in the progression of canine MCTs [36].

In addition to $c$-KIT mutations, aberrant KIT expression and more specifically, the aberrant localization of KIT has been described in canine cutaneous MCTs [40-42]. Recently our laboratory has identified 3 patterns of KIT protein localization in canine MCTs: 1 . peri-membrane KIT localization (KIT pattern 1); 2. cytoplasmic stippling to focal KIT localization (KIT pattern 2); 3. diffuse cytoplasmic KIT localization (KIT pattern 3), as shown in Figure 2. Recent studies have shown that canine MCTs that have a primarily cytoplasmic pattern of KIT protein localization (KIT patterns 2 and 3) have a significantly worse prognosis, in terms of both their disease-free interval and survival duration, as compared to MCTs that have a primarily peri-membrane pattern of KIT localization [41]. Furthermore, we have found that ITD $c$-KIT mutations in canine MCTs are significantly associated with aberrant KIT localization in neoplastic mast cells. However, a substantial number of canine MCTs have aberrant KIT localization, but do not have ITD mutations [36]. This suggests that additional factors, aside from ITD $c$-KIT mutations may be responsible for aberrant KIT localization in neoplastic mast cells.

Despite the high incidence of $c$-KIT kinase domain mutations in human patients with mastocytosis, only a total of 18 canine MCTs and 3 canine MCT cell lines have been 


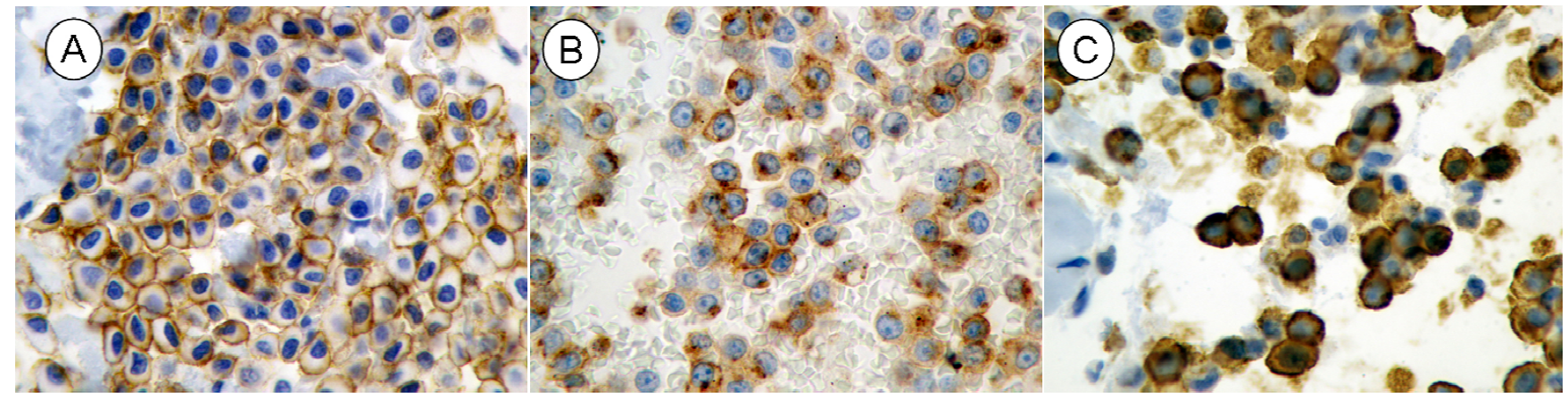

\section{Figure 2}

Immunohistochemical staining patterns of canine cutaneous MCTs staining with anti-KIT antibodies. A. KIT staining pattern I: peri-membrane KIT protein localization; B. KIT staining pattern 2: focal or stippled cytoplasmic KIT protein localization; C. KIT staining pattern 3: Diffuse cytoplasmic KIT localization. Canine MCTs with KIT staining patterns 2 and 3 that lacked ITD c-KIT mutations were screened for mutations in c-KIT exon I7. B and C show MCTs with aberrant KIT localization that lack ITD cKIT mutations.

evaluated for kinase domain mutations in $c$-KIT $[33,34]$. For a more detailed evaluation of possible $c$-KIT kinase domain mutations in canine MCTs, we screened exons 16-20 of the phospho-transferase portion of the kinase domain of $c$-KIT for mutations that may contribute to the progression of these tumors. Additionally, in order to determine if mutations in exon 17 of $c$-KIT, where the majority of mutations occur in human mastocytosis patients, were responsible for aberrant KIT localization, exon 17 was screened in 18 MCTs with aberrant KIT localization that lack ITD $c$-KIT mutations. However, no mutations or polymorphisms were identified in exons 16-20 of any of the canine MCTs that were examined.

\section{Methods \\ Study population}

Samples from 33 canine cutaneous MCTs from 33 dogs were obtained from archival formalin-fixed paraffinembedded tissues that had been submitted to the Diagnostic Center for Population and Animal Health at Michigan State University. Single paraffin blocks with neoplastic tissue were selected for each tumor and each tumor was histologically graded based on the Patnaik histologic grading system [43] for canine cutaneous MCTs.

\section{DNA isolation from formalin-fixed paraffin embedded tissues}

Tissue samples for DNA isolation were selected within the tumor boundaries, as identified by histologic evaluation. Approximately $2 \mathrm{~mm}^{3}$ tissue samples were obtained from each block for DNA extraction. DNA was isolated as previously described $[35,44]$. In brief, $400 \mu$ l of digestion buffer (50 mM Tris, pH 8.5, 1 mM EDTA, 0.5\% Tween) was added to each sample. Samples were heated to $95^{\circ} \mathrm{C}$ for 10 minutes followed by heating in a microwave at full power twice for 30 seconds. Samples were thoroughly vor- texed between each heating step. $5 \mu \mathrm{l}$ of $15 \mathrm{mg} / \mathrm{ml}$ proteinase $\mathrm{K}$ was added to each sample, and the samples were subsequently incubated overnight at $42^{\circ} \mathrm{C}$. Proteinase $\mathrm{K}$ was inactivated at $95^{\circ} \mathrm{C}$ for 10 minutes. Samples were then centrifuged and $200 \mu \mathrm{l}$ of the reaction was aliquoted for use as template in PCR.

\section{Amplification of c-KIT exons 16-20}

PCR amplification was carried out using primer pairs that flanked exons $16,17,18,19$, and 20 in order to sequence each exon in its entirety and the 10-20 nucleotides that flank each exon (Table 1, Figure 3). Twenty-five microliter PCR reactions were prepared with $5 \mu \mathrm{l}$ DNA at a 1:25 dilution, 5 pmol of each primer, 0.5 units of Taq polymerase (Invitrogen, Carlsbad, CA), and final concentrations of 80 $\mu \mathrm{M}$ dNTPs, $2 \mathrm{mM} \mathrm{MgCl}$, $20 \mathrm{mM}$ Tris- $\mathrm{HCl}$, and $50 \mu \mathrm{KCl}$. Cycling conditions for amplifying exons 16, 17, 18, and 20 were as follows: $94^{\circ} \mathrm{C}$ for 4 minutes; 40 cycles at $94^{\circ} \mathrm{C}$ for 1 minute, $60^{\circ} \mathrm{Cfor} 1$ minute, and $72^{\circ} \mathrm{C}$ for 1 minute; $72^{\circ} \mathrm{C}$ for 5 minutes. Cycling conditionswere similar for exon 19 , except a $54^{\circ} \mathrm{C}$ annealing temperature was used instead of a $60^{\circ} \mathrm{C}$ annealing temperature. Amplified products were visualized by agarose gel electrophoresis on a $2 \%$ agarose gel stained with ethidium bromide.

\section{Sequencing of c-KIT exons I6-20}

Amplified products were pooled in groups of 7-10 for DNA sequencing whenever possible, as previously described [45]. This pool and sequence method has been shown to allow for the detection of minor alleles at frequencies as low as 5\%. If clean sequences were not obtained from pooled samples, then samples were sequenced individually. DNA to be sequenced was separated on a $2 \%$ agarose gel, and DNA fragments were excised for DNA purification. DNA was purified using the Qiaex II gel purification kit (Qiagen, Valencia, CA) 
Table I: Primers used for PCR amplification of c-KIT exons I6-20 and size of expected PCR products for each primer pair.

\begin{tabular}{cclcc}
\hline Exon & Primer Number & Direction & Sequence & Product Size (bp) \\
\hline \multirow{2}{*}{16} & 1202 & Forward & CTT TGA GGC TTA ATT GCT AAG AA & 256 \\
& 1203 & Reverse & ACT ATG AAC TCT AAA ATG CGC CA & 261 \\
17 & 1204 & Forward & ATA GCA GCA TTC TCG TGT TG & 189 \\
18 & 1205 & Reverse & AAC TAA AAT CCT TCA CTG GAC TG & 188 \\
19 & 1206 & Forward & AGA TGC TCT CGC CCA ACC A & 189 \\
20 & 1207 & Reverse & GGG TCC TGC TTG CTT ATT & \\
& 1208 & FGC ATG ATC TCA AGG GAA & \\
& 1209 & Reverse & AGG CTA AGG GCG TTG AGG & \\
\hline
\end{tabular}

according to manufacturer's protocol. DNA sequencing was carried out using the Thermo Sequenase radiolabeled terminator cycle sequencing kit (Amersham, Piscataway, $\mathrm{NJ})$, following manufacturer's instruction. Sequence reactions were separated on a $6 \%$ denaturing polyacrylamide gel, which was dried and exposed to BioMax MR scientific imaging film (Kodak, Rochester, NY) for 72 hours for visualization.

\section{DNA isolation from laser capture microdissected tumor samples}

Eighteen MCTs with aberrant KIT localization, but no ITD $c$-KIT mutations were identified as part of a previous study [36] (figure 3. Seven micron sections of each MCT were dehydrated and stained with hematoxylin for laser capture microdissection. 2,000-4,000 neoplastic mast cells were extracted from each tumor sample using the Pixcell laser capture microdissection system with Macro LCM caps (Arcturus, Mountain View, CA). LCM caps adhered to extracted cells were incubated inverted overnight in $50 \mu \mathrm{l}$ of DNA extraction buffer (10 mM Tris pH 8.0, $1 \mathrm{mM}$ EDTA, $1 \%$ Tween) and $1.5 \mu \mathrm{l}$ of $15 \mathrm{mg} / \mathrm{ml}$ Proteinase $\mathrm{K}$ at $37^{\circ} \mathrm{C}$. Samples were centrifuged at $1306 \times \mathrm{g}$ for 5 minutes, and Proteinase $\mathrm{K}$ was inactivated by heating at $95^{\circ} \mathrm{C}$ for 8 minutes. $5 \mu \mathrm{l}$ of DNA was used for each $25 \mu \mathrm{l}$ reaction. PCR reactions were prepared using primers flanking $c$-KIT exon 17 as described above.

\section{Results}

Thirty-three cutaneous MCTs from 33 dogs were included in this study. The age of these dogs ranged from 2.5-15 years with an average of 7.42 years. Twenty of the 33 dogs were female and 13 were male. The breed distribution of this study population included 10 boxers, 9 Labrador retrievers, 5 golden retrievers, 1 Boston terrier, 1 Bichon Frise and 7 mixed breed dogs. All MCTs were graded according to the Patnaik histologic grading system for canine cutaneous mast cell tumors [43]. Twelve of the 33 MCTs were histologic grade 1, 18 were grade 2, and 3 were grade 3 . All 33 MCTs included in this study were previously screened for mutations in the juxtamembrane domain of $c$-KIT. No internal tandem duplications or deletions were identified in the juxtamembrane domain of $c$-KIT in any of the MCTs included in this study (data not shown).

In order to identify potential activating mutations $c$-KIT exons $16,17,18,19$, and 20 , which encode the phosphotransferase region of the kinase domain of the KIT protein, were amplified using PCR amplification and sequenced. Exons 16 to 20 were identical to previously published cDNA sequences of the canine c-KIT gene [Genbank: $\underline{A F 448148]}$ in all canine MCTs examined. No mutations or polymorphisms were identified in c-KIT exons 16 to 20 in any of the canine cutaneous MCTs screened. One single nucleotide polymorphism was identified at the $7^{\text {th }}$ nucleotide of intron 18 consisting of a $\mathrm{C}$ to A transversion.

Previous work by our laboratory has identified a correlation between ITD $c$-KIT mutations and aberrant KIT localization in canine cutaneous MCTs. However, we have also found that a subset of canine cutaneous MCTs have aberrant KIT localization without having ITD $c$-KIT mutations [36]. In human mastocytosis patients, mutations of $c$-KIT are commonly seen in exon $17[19,24,25]$. In order to test the hypothesis that mutations in $c$-KIT exon 17 are responsible for aberrant KIT localization in canine MCTs that lack ITD $c$-KIT mutations, exon 17 was amplified and sequenced from 18 such cases. Exon 17 was identical to previously published $c$-KIT sequences [Genbank:AF448148] and no mutations or polymorphisms were identified in exon 17 in any of the canine MCTs evaluated.

\section{Discussion}

This study did not identify any mutations of the phosphotransferase domain of $c$-KIT in 33 canine cutaneous MCTs examined. These findings are also supported by reports from London et al. in which 11 MCTs were examined for kinase domain mutations [33]. Therefore, it is highly unlikely that the phospho-transferase domain of $c$-KIT plays a role in the progression of canine MCTs. Further- 


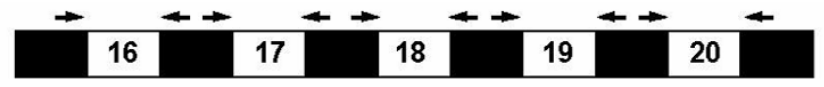

Figure 3

Schematic Diagram of Primer Design for Polymerase Chain Reaction. Forward and reverse primers (arrows) were designed in introns (black boxes) flanking exons 16, 17, 18, 19, and 20 (white boxes).

more, mutations in exon 17 of the $c$-KIT proto-oncogene, where mutations are most commonly seen in human patients with mastocytosis $[19,24,25]$, do not contribute to the aberrant localization of KIT in canine cutaneous MCTs.

The kinase domain of $c$-KIT is highly conserved between humans and canines. In a comparison of the human [Genbank: NM_000222] and canine [Genbank: AF448148] amino acid sequences corresponding to exons $16-20$, there is only a single difference in which a glutamate in the human is replaced with an aspartate residue in exon 20 of the dog, giving greater than 99\% identity between these species (figure 4 ). The high degree of conservation between the human and the dog suggests that a change in a single amino acid of the kinase domain could alter the function of the KIT protein, potentially producing a constitutively activated protein, as is seen in human mastocytosis patients. However, unlike human mastocytosis patients, kinase domain $c$-KIT mutations do not appear to play a role in the progression of canine MCTs.

Internal tandem duplications and deletions in the juxtamembrane domain of $c$-KIT have been identified in approximately $15 \%$ of canine MCTs [36]. The internal tandem duplication mutations are the most frequent and best characterized $c$-KIT mutations in canine MCTs [35,38]. All of the characterized ITD mutations result in a constitutively activated KIT product, which is characterized by the constitutive phosphorylation of the receptor in the absence of ligand binding $[33,34,39]$. Considering the role of $c$-KIT in mast cell survival and proliferation $[10,17]$ and the association between ITD $c$-KIT mutations and decreased disease-free interval and survival duration of dogs [36], c-KIT appears to play a key role in the progression of canine MCTs [36]. Therefore, $c$-KIT may also represent a potential therapeutic target for canine cutaneous MCTs [35-37,39,41,46].

Juxtamembrane domain $c$-KIT mutations have only been found in approximately $15 \%$ of all canine MCTs $[35,36]$ and $50 \%$ of high grade MCTs [37]. We hypothesized that phospho-transferase domain $c$-KIT mutations may play a role in the progression of canine cutaneous MCTs that lack ITD $c$-KIT mutations. The goal of this study was to investigate the presence of any activating mutations in the phospho-transferase domain of the $c$-KIT proto-oncogene. The results of this study suggest that $c$-KIT mutations of the phospho-transferase domain do not play a significant role in the progression of canine MCTs. Since some small molecule kinase inhibitors have shown a greater efficacy in tumors with mutations in the target receptor tyrosine kinase (e.g. KIT) $[39,47,48]$, MCTs lacking $c$-KIT mutations may not be as good of candidates for the treatment with these drugs. Therefore, other genetic or epigenetic changes that play a role in the progression of canine MCTs need to be identified in order to develop targeted treatment strategies in those MCTs that lack ITD $c$-KIT mutations. However, additional domains of the $c$-KIT proto-oncogene still need to be evaluated for the presence of activating mutations in canine MCTs. One area of particular interest is, the extracellular ligand-binding domain where mutations have been identified in exon 8 of human familial mastocytosis and GIST patients [49] and exon 9 of human GIST patients $[48,50,51]$.

Additional work from our laboratory has shown a correlation between ITD $c$-KIT mutations and the aberrant localization of KIT in canine MCTs [36]. These results suggest that ITD $c$-KIT mutations may lead to the aberrant cytoplasmic localization of KIT in at least a subset of canine MCTs. Despite this correlation between ITD mutations and aberrant KIT localization, we have identified some MCTs that have aberrant KIT localization, but do not have ITD $c$-KIT mutations [36]. We hypothesized that point mutations in exon 17 of the $c$-KIT proto-oncogene, similar to those seen in human patients with mastocytosis, are responsible for the aberrant KIT localization in MCTs without ITD $c$-KIT mutations. However, in this study we did not find any mutations in exon 17 of the $c$-KIT protooncogene in 18 canine cutaneous MCTs with aberrant KIT localization. These results suggest that other changes to $c$ $K I T$, such as mutations in other $c$-KIT domains, changes in transcriptional regulation or alternative splicing, or other cellular changes, such as changes in golgi processing or intracellular trafficking may be responsible for aberrant KIT localization and may therefore play a role in the progression of canine cutaneous MCTs.

\section{Conclusion}

In this study no kinase domain $c$-KIT mutations were found in any canine cutaneous MCT examined and therefore these mutations do not appear to play a significant role in the progression of this disease. In accordance with this data, exon $17 c$-KIT mutations do not appear to be responsible for aberrant KIT localization in canine MCTs with aberrant KIT localization that lack ITD $c$-KIT mutations. Due to the relatively low incidence of juxtamembrane domain $c$-KIT mutations, and the lack of kinase domain mutations in canine cutaneous MCTs, further 


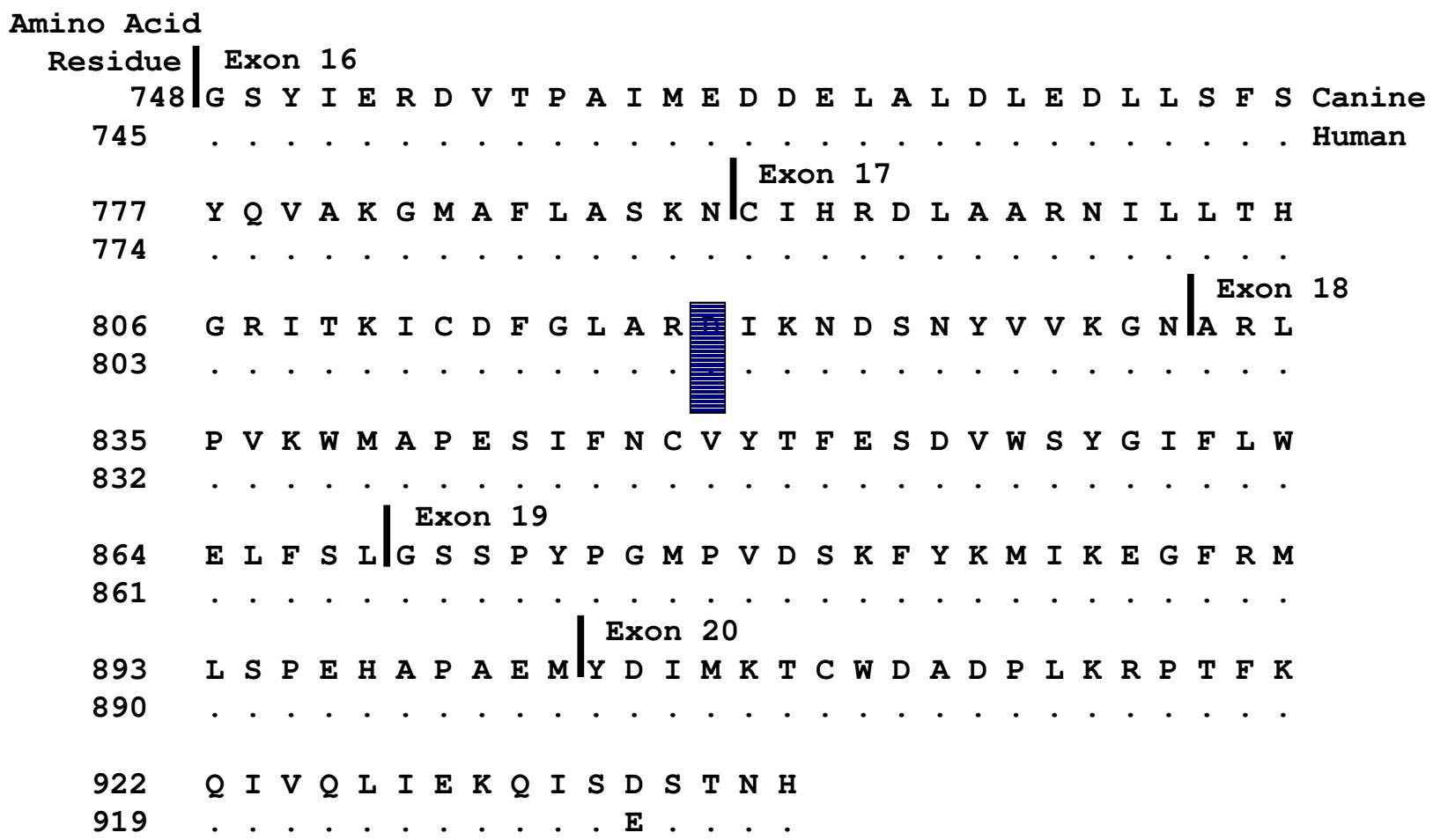

\section{Figure 4}

Amino acid alignment of the kinase domain (exons 16-20) of canine and human KIT. Canine and human amino acid alignments demonstrate a $99.5 \%$ identity between the phospho-transferase portion of the kinase domain of these species. Codon 816 , which is commonly mutated in human mastocytosis patients (D8I6V; shaded residue) is also conserved in canine KIT.

studies are necessary to identify additional factors and genes that lead to the progression of canine cutaneous MCTs. Although targeting constitutively activated KIT protein in canine MCTs offers great promise for the treatment of canine MCTs $[39,46]$, such a therapeutic approach may not be justified for all MCTs. A significant number of MCTs seem to have no alterations in the $c$-KIT protooncogene, and targeted inhibition of this gene will therefore have little or no effect on these tumors. Therefore, additional studies need to be performed in order to determine other factors that may be involved in the progression of canine MCTs without ITD $c$-KIT mutations in order to identify potential targets in those tumors.

\section{Competing interests}

The author(s) declare that they have no competing interests.

\section{Authors' contributions}

JDW carried out the PCR amplification and sequencing of this study, with technical assistance from Daniel Zemke, Elizabeth Kruszewski, and Angela Sosin, and drafted the manuscript.
MK participated in the design of the study and helped draft the manuscript.

VYG participated in the design of the study, coordinated the study and helped draft the manuscript.

All authors red and approved the final manuscript.

\section{Acknowledgements}

The authors would like to acknowledge Dr. Daniel Zemke, Elizabeth Kruszewski, and Angela Sosin for their technical assistance. Funding for this study was provided in part by the Companion Animal Fund of the College of Veterinary Medicine, Michigan State University. JDW is funded by NIH T-32 post-doctoral training grant number RR I7I89.

\section{References}

I. Yarden Y, Escobedo JA, Kuang WJ, Yang-Feng TL, Daniel TO, Tremble PM, Chen EY, Ando ME, Harkins RN, Francke U, Fried VA, Ullrich A, Williams LT: Structure of the receptor for platelet-derived growth factor helps define a family of closely related growth factor receptors. Nature 1986, 323:226-232.

2. Yarden Y, Kuang W, Yang-Feng T, Coussens L, Munemitsu S, Dull TJ, Chen E, Schlessinger J, Francke U, Ullrich A: Human proto-oncogene c-kit: a new cell surface receptor tyrosine kinase for an unidentified ligand. EMBO 1987, 6:334I-335I. 
3. Chan PM, llangumaran S, La Rose J, Chakrabartly A, Rottapel R: Autoinhibition of the KIT receptor tyrosine kinase by cystolic juxtamembrane region. Mol Cel Biol 2003, 23:3067-3078.

4. Nocka K, Majumder S, Chabot B, Ray P, Cervone M, Bernstein A, Besmer $P$ : Expression of $c-k i t$ gene products in known cellular targets of $W$ mutations in normal and $W$ mutant miceevidence for an impaired c-kit kinase in mutant mice. Genes Dev 1989, 3:816-826.

5. Natali PG, Nicotra MR, Sures I, Santoro E, Bigotti A, Ullrich A: Expression of c-kit receptor in normal and transformed human nonlymphoid tissues. Cancer Res 1992, 53:6 I39-6I43.

6. Matsuda R, Takahashi T, Nakamura S, Sekido Y, Nishida K, Seto M, Seito T, Sugiura T, Ariyoshi Y, Takahashi T, Ueda R: Expression of the c-kit protein in human solid tumors and in corresponding fetal and adult normal tissues. Am I Pathol I993, I42:339-346.

7. Tsuura Y, Hiraki H, Watanabe K, Igarashi S, Shimamura K, Fukuda T, Suzuki T, Seito T: Preferential localization of c-kit product in tissue mast cells, basal cells of skin, epithelial cells of breast, small cell lung carcinoma, and seminomas/dysgerminoma in humans: immunohistochemical study on formalin-fixed, paraffin-embedded tissues. Virchows Arch 1994, 424:135-141.

8. Arber DA, Tamayo R, Weiss LM: Paraffin section detection of the c-kit gene product (CD I I 7) in human tissues: value in the dagnosis of mast cell disorders. Hum Pathol 1998, 29:498-504.

9. Huang E, Nocka K, Beler DR, Chu TY, Buck J, Lahm HW, Wellner D, Leder $\mathrm{P}$, Besmer $\mathrm{P}$ : The hematopoietic growth factor $\mathbf{K L}$ is encoded by the SI locus and is the ligand of the c-kit receptor, the gene product of the W locus. Cell 1990, 63:225-233.

10. Nocka K, Buck J, Levi E, Besmer P: Canidate ligand for the c-kit transmembrane kinase receptor: $K L$, a fibroblast derived growth factor stimulates mast cells and erythroid progenitors. EMBO 1990, 9:3287-3294.

II. Zsebo KM, Wypych J, McNiece IK, Lu HS, Smith KA, Karkare SB Sachdev RK, Yuschenkoff VN, Birkett NC, Williams LR, Satyagal VN, Tung W, Bosselman RA, Mendiaz EA, Langley KE: Identification, purification, and biological characterization of hematopoietic stem cell factor from bull rat liver-conditioned medium. Cell 1990, 63:195-201.

12. Zsebo KM, Williams DA, Geissler EA, Broudy VC, Martin FH, Atkins HL, Hsu RY, Birkett NC, Okino KH, Murdock DC, Jacobsen FW, Langley KE, Smith KA, Takeishi T, Cattanach BM, Galli SJ, Suggs SV: Stem cell factor is encoded at the SI locus of the mouse and is the ligand for the c-kit tyrosine kinase receptor. Cell 1990, 63:213-224.

13. Tsai M, Takeishi T, Thompson H, Langley KE, Zsebo KM, Metcalfe DD, Geissler EN, Galli SJ: Induction of mast cell proliferation, maturation and heparin synthesis by the rat c-kit ligand, stem cell factor. Proc Ntl Acad Sci USA 1991, 88:6382-6386.

14. Columbo M, Horowitz EM, Botana LM, MacGlashan DW, Bochner BS, Gillis S, Zsebo KM, Galli SJ, Lichtenstein LM: The human recombinant c-kit receptor ligand, rhSCF, induces mediator release from human cutaneous mast cells and enhances IgEdependent mediator release from both skin mast cells and peripheral blood basophils. J Immunol 1992, I 49:599-608.

15. Meininger CJ, Yano H, Rottapel R, Bernstein A, Zsebo KM, Zetter BR: The c-kit receptor ligand functions as a mast cell chemoattractant. Blood 1992, 79:958-963.

16. Dastych J, Metcalfe DD: Stem cell factor induces mast cell adhesion to fibronectin. I Immunol 1994, I 52:213-219.

17. Yee NS, Paek I, Besmer P: Role of kit-ligand in proliferation and suppression of apoptosis in mast cells: basis for radiosensitivity of white spotting and steel mutant mice. J Exp Med 1994 I 79: 1777-1787.

18. Furitsu $T$, Tsujimura $T$, Tono $T$, Ikeda $H$, Kitayama $H$, Koshimizu $U$, Sagahara H, Butterfield JH, Ashman LK, Kanayama Y, Matsuzawa Y, Kitamura $Y$, Kanakura $Y$ : Identification of mutations in the coding sequence of the proto-oncogene c-kit in a human mast cell leukemia cell line causing ligand-independent activation of c-kit product. / Clin Invest 1993, 92: 1736-I744.

19. Nagata H, Worobec AS, Oh CK, Chowdhury BA, Tannenbaum S, Suzuki $Y$, Metcalfe DD: Identification of a point mutation in the catalytic domain of proto-oncogene c-kit in peripheral blood mononuclear cells of patients who have mastocytosis with an associated hematologic disorder. Proc NtI Acad Sci USA 1995, 92:10560-10564.
20. Longley BJ, Tyrrell L, Lu SZ, Ma YS, Langley K, Ding T, Duffy T, Jacobs $P$, Tang LH, Modlin I: Somatic c-kit activating mutation in utricaria pigmentosa and aggressive mastocytosis: establishment of clonality in a human mast cell neoplasm. Nature Genetics 1996, I 2:312-314.

21. Tian Q, Frierson HF, Krystal GW, Moskaluk CA: Activating c-kit gene mutations in human germ cell tumors. Am J Pathol I999, I54: I643-1647.

22. Sakuma Y, Sakuri S, Oguni S, Hironaka M, Saito K: Alterations of the c-kit gene in testicular germ cell tumors. Cancer Sci 2003, 94:486-49I.

23. Hirota $S$, Isozaki K, Moriyama $Y$, Hashimoto K, Nishida T, Ishiguro S, Kawano K, Hanada M, Kurata A, Takeda M, Tunio GM, Matsuzawa Y, Kanakura Y, Shinomura Y, Kitamura Y: Gain-of-function mutations of c-kit in human gastrointestinal stromal tumors. Science 1998, 279:577-580.

24. Worobec AS, Semer T, Nagata H, Metcalfe DD: Clinical correlates of the presence of Asp8 I $6 \mathrm{Val}$ c-kit mutation in the peripheral blood mononuclear cells of patients with mastocytosis. Cancer 1998, 83:2120-2129.

25. Longley BJ, Metcalfe DD, Tharp M, Wang X, Tyrrell L, Lu S, Heitjan $\mathrm{D}, \mathrm{Ma} \mathrm{Y}$ : Activating and dominant inactivating c-kit catalytic domain mutations in distinct clinical forms of human mastocytosis. Proc Ntl Acad Sci USA 1999, 96: I609-16।4.

26. LaSota J, Jasinski M, Sarlomo-Rikala M, Miettinen M: Mutations in exon I I of c-kit occur preferentially in malignant versus benign gastrointestinal stromal tumors and do not occur in leiomyomas or leioyosarcomas. Am J Pathol 1999, I 54:53-60.

27. Taniguchi M, Nishida T, Hirota S, Isozaki K, Ito T, Nomura T, Matsuda $H$, Kitamura $Y$ : Effect of c-kit mutation on prognosis of gastrointestinal stromal tumors. Cancer Res 1999, 59:4297-4300.

28. Brodey RS: Canine and feline neoplasia. Adv in Vet Sci Comp Med 1970, 14:309-354.

29. Preister WA: Skin tumors in domestic animals. Data from $\mathbf{~} 2$ United States and Canadian colleges of veterinary medicine. J Ntl Cancer Inst 1973, 50:457-466.

30. Finnie JW, Bostock DE: Skin neoplasia in dogs. Australian Veterinary Journal 1979, 55:602-604.

31. Rothwell TLW, Howlett CR, Middleton DJ, Griffiths DA, Duffs BC: Skin neoplasms of dogs in Sydney. Aust Vet J 1987, 64: 16I-I64.

32. Misdorp W: Mast cells and canine mast cell tumors: a review. Vet $Q$ 2004, 26: I56-169.

33. London CA, Galli SJ, Yuuki T, Hu ZQ, Helfand SC, Geissler EN: Spontaneous canine mast cell tumors express tandem duplications in the proto-oncogene. c-KIT 1999, 27:689-697.

34. Ma Y, Longley BJ, Wang X, Blount JL, Langley K, Caughey GH: Clustering of activating mutations in c-KIT 's juxtamembrane coding region in canine mast cell neoplasms. J Invest Dermatol 1999, I I 2: I 65-I70

35. Zemke D, Yamini B, Yuzbasiyan-Gurkan V: Mutations in the juxtamembrane domain of c-KIT are associated with higher grade mast cell tumors in dogs. Vet Pathol 2002, 39:529-535.

36. Webster JD, Yuzbasiyan-Gurkan V, Kaneene JB, Miller R, Resau JH, Kiupel $M$ : The role of $c-K I T$ in tumorigenesis:evaluation in canine cutaneous mast cell tumors. Neoplasia in press.

37. Downing S, Chien MB, Kaas PH, Moore PE, London CA: Prevalence and importance of internal tandem duplications in exons I I and 12 of c-KIT in mast cell tumors of dogs. Am J Vet Res 2002, 63: $1718-1723$.

38. Jones CLR, Grahn RA, Chien MB, Lyons LA, London CA: Detection of c-KIT mutations in canine mast cell tumors using fluorescent polyacrylamide gel electrophoresis. J Vet Diagn Invest 2004, 16:95-100.

39. Pryer NK, Lee LB, Zadovaskaya R, Yu X, Sukbuntherng J, Cherrington JM, London CA: Proof of target for SUI I 654: inhibition of KIT phosphorylation in canine mast cell tumors. Clin Cancer Res 2003, 9:5729-5734.

40. Reguera MJ, Rabanal RM, Puigdemont A, Ferrer L: Canine mast cell tumors express stem cell factor receptor. Am J Dermatopatho 2000, 22:49-54.

4I. Webster JD, Kiupel M, Kaneene JB, Miller R, Yuzbasiyan-Gurkan V: The use of KIT and tryptase expression patterns as prognostic tools for canine cutaneous mast cell tumors. Vet Pathol 2004, 4 I:37I-377. 
42. Preziosi R, Morini M, Sarli G: Expression of the KIT protein (CDII7) in primary cutaneous mast cell tumors of the dog. J Vet Diagn Invest 2004, 16:554-56I.

43. Patnaik AK, Ehler WJ, MacEwen EG: Canine cutaneous mast cell tumor: morphologic grading and survival time in 83 dogs. Vet Pathol 1984, $21: 469-474$.

44. Banerjee SK, Makdisi WF, Weston AP, Mitchell SM, Campell DR: Microwave-based DNA extraction from paraffin-embedded tissue for PCR amplification. BioTechniques 1995, 18:768-773.

45. Brouillette JA, Andrew JR, Venta PJ: Estimate of nucleotide diversity in dogs with a pool-and -sequence method. Mamm Genome 2000, II:1079-1086

46. Liao AT, Chien MB, Shenoy N, Mendel DB, McMahon G, Cherrington JM, London CA: Inhibition of constitutively active forms of mutant KIT by multitargeted indolinone tyrosine kinase inhibitors. Blood 2002, 15:585-593.

47. Debiec-Rychter M, Dumez H, Judson I, Wasag B, Berweij J, Brown M, Dimitrijevic S, Sciot R, Stul M, Vranck H, Scurr M, Hagemeijer A, Glabbeke M, van Oosterom AT: Use of c-KIT /PDGFR mutational analysis to predict the clinical response to imatinib in patients with advanced gastrointestinal stromal tumours entered on phase I and II studies of the EORTC Soft Tissue and Bone Sarcoma Group. Eur J Cancer 2004, 40:689-695.

48. Heinrich MC, Corless CL, Demetri GD, Blanke CD, von Mehren M, Joensuu H, McGreevey LS, Chen CJ, Van den Abbeele AD, Druker BJ Kiese B, Eisenberg B, Roberts PJ, Singer S, Fletcher CDM, Silberman $S$, Dimitrijevic, Fletcher JA: Kinase mutations and imatinib response in patients with metastatic gastrointestinal stromal tumor. J Clin Oncol 2003, 21:4342-4349.

49. Hartmann K, Wardelmann E, Ma Y, Merkelbach-bruse S, Preussner LM, Carla W, Baldus SE, Heinicke T, Thiele J, Buettner R, Longley B]: Novel germline mutation of KIT associated with familial gastrointestinal stromal tumors and mastocytosis. Gastroenterol 2005, I 29: I042-1046.

50. Rubin BP, Singer S, Tsao C, Duensing A, Lux ML, Ruiz R, Hibbard MK Chen CJ, Xiao S, Tuveson DA, Demetri GD, Fletcher CDM, Fletcher JA: KIT activation is a ubiquitous feature in gastrointestina stromal tumors. Cancer Res 2001, 61:8118-8121.

5I. Penzel R, Aulmann S, Moock M, Schwarzbach M, Rieker RJ, Mechtersheimer G: The location of KIT and PDGFRA gene mutations in gastrointestinal stromal tumours is site and phenotype associated. J Clin Pathol 2005, 58:634-639.

\section{Pre-publication history}

The pre-publication history for this paper can be accessed here:

http://www.biomedcentral.com/1471-2407/6/85/prepub

\section{Publish with Biomed Central and every scientist can read your work free of charge}

"BioMed Central will be the most significant development for disseminating the results of biomedical research in our lifetime. "

Sir Paul Nurse, Cancer Research UK

Your research papers will be:

- available free of charge to the entire biomedical community

- peer reviewed and published immediately upon acceptance

- cited in PubMed and archived on PubMed Central

- yours - you keep the copyright
BioMedcentral 